\title{
Language Conflict in Algeria
}




\section{MULTILINGUAL MATTERS}

Series Editor: John Edwards, St. Francis Xavier University, Canada

Multilingual Matters series publishes books on bilingualism, bilingual education, immersion education, second language learning, language policy, multiculturalism. The editor is particularly interested in 'macro' level studies of language policies, language maintenance, language shift, language revival and language planning. Books in the series discuss the relationship between language in a broad sense and larger cultural issues, particularly identity related ones.

Full details of all the books in this series and of all our other publications can be found on http://www.multilingual-matters.com, or by writing to Multilingual Matters, St Nicholas House, 31-34 High Street, Bristol BS1 2AW, UK. 


\section{Language Conflict in Algeria}

From Colonialism to Post-Independence

Mohamed Benrabah 


\section{In memory of my parents, And for Selina and Mohamed Nouri Amine}

\section{Library of Congress Cataloging in Publication Data}

Benrabah, Mohamed.

Language Conflict in Algeria: From Colonialism to Post-Independence/Mohamed Benrabah.

Multilingual Matters: 154 .

Includes bibliographical references and index.

1. Languages in contact-Algeria. 2. Arabic language-Algeria-History. 3. Language policy-Algeria. 4. Language and education-Algeria. 5. Sociolinguistics-AlgeriaHistory. 6. Algeria-Languages-Political aspects. I. Title.

P130.52.A4B46 2013

306.44'60965-dc23 2013001853

\section{British Library Cataloguing in Publication Data}

A catalogue entry for this book is available from the British Library.

ISBN-13: 978-1-84769-964-0 (hbk)

\section{Multilingual Matters}

UK: St Nicholas House, 31-34 High Street, Bristol BS1 2AW, UK.

USA: UTP, 2250 Military Road, Tonawanda, NY 14150, USA.

Canada: UTP, 5201 Dufferin Street, North York, Ontario M3H 5T8, Canada.

Copyright (c) 2013 Mohamed Benrabah.

All rights reserved. No part of this work may be reproduced in any form or by any means without permission in writing from the publisher.

The policy of Multilingual Matters/Channel View Publications is to use papers that are natural, renewable and recyclable products, made from wood grown in sustainable forests. In the manufacturing process of our books, and to further support our policy, preference is given to printers that have FSC and PEFC Chain of Custody certification. The FSC and/or PEFC logos will appear on those books where full certification has been granted to the printer concerned.

Typeset by Techset Composition Ltd., Salisbury, UK.

Printed and bound in Great Britain by the MPG Printgroup. 


\section{It's a tough job being Algerian}

Tahar Djaout* (quoted in Šukys, 2007: 14)

* Tahar Dajout is the first writer-journalist assassinated during the purge of intellectuals in Algeria in the 1990s. His murder in May 1993 attributed to Islamist extremists put an end to a promising writing career. 